\title{
FINANSYZACJA GOSPODARKI W UJĘCIU MAKROEKONOMICZNYM
}

\section{WPROWADZENIE}

Upowszechnienie się zjawiska finansyzacji w najwyżej rozwiniętych gospodarkach kapitalistycznych świata zachodniego oraz proces naśladownictwa w licznych krajach rozwijających się wydają się uprawniać do konstatacji, że w procesach tych w istocie nastapiło redefiniowanie ekonomicznej roli sektora finansowego w gospodarce. Ze służebnej, podporządkowanej funkcji pośrednika finansowego oraz mediatora i katalizatora w procesach gospodarczych sektor finansowy stał się w licznych przypadkach kreatorem nadrzędnych reguł i zasad, do których muszą dostosowywać się podmioty z realnych sektorów gospodarki. W literaturze odnaleźć można pogląd, zgodnie z którym w procesie finansyzacji sektor finansowy zmienił optykę i logikę funkcjonowania podmiotów gospodarczych. Jest on również odpowiedzialny za fundamentalne przekształcenia wybranych rynków i sektorów, a także doprowadził do modyfikacji zachowań gospodarstw domowych oraz relacji społecznych. Dominacja motywów finansowych, zwłaszcza tych o charakterze krótkookresowym, objęła tak liczne obszary, że w odniesieniu do niektórych gospodarek narodowych ze wszech miar uzasadnione jest używanie określenia „gospodarka sfinansyzowana” czy też terminu „finansyzacja gospodarki".

Celem artykułu jest zaprezentowanie holistycznego spojrzenia na problematykę finansyzacji, opartego na krytycznej analizie literatury. Jest to jednocześnie zasadnicza cecha odróżniająca niniejsze opracowanie od podobnych artykułów publikowanych dotychczas na gruncie krajowej literatury, które w zdecydowanej większości przypadków dotykają i analizuja, częstokroć w sposób szczegółowy, jedynie wybrane aspekty rzeczonego zjawiska. Wartość dodana, jaką niniejsze opracowanie wnosi do polskiego dyskursu poświęconego finansyzacji, przejawia się również w zaproponowaniu, jak się wydaje, nowego spojrzenia na to zjawisko, a mianowicie jego analizie w wymiarze makroekonomicznym. Artykuł składa się z trzech części. Przedmiotem rozważań w części pierwszej są kwestie definicyjne. Część druga poświęcona jest syntetycznej analizie tła historycznego oraz ukazaniu etapów rozwoju zjawiska finansyzacji. W części trzeciej centralną oś wywodu stanowią makroekonomiczne aspekty zjawiska finansyzacji gospodarki. 


\section{POJĘCIE FINANSYZACJI ORAZ ISTOTA ZJAWISKA}

W literaturze przedmiotu jest prezentowany pogląd, że intelektualnymi pionierami, jeśli chodzi o identyfikację trendu związanego ze zjawiskiem finansyzacji, byli Harry Magdoff i Paul Sweezy. Wskazywali oni na zjawisko swoistej ucieczki kapitału do sfery finansowej, co było ich zdaniem rezultatem ograniczonych możliwości inwestycyjnych w sferze produkcyjnej. Samo pojęcie finansyzacji zostało wprowadzone do obiegu naukowego przez Gérarda de Bernisa, natomiast po raz pierwszy pojawiło się w książce autorstwa Kevina Philipsa, który utożsamiał je z długotrwałym rozłamem pomiędzy rozbieżnymi systemami gospodarki realnej i gospodarki finansowej ${ }^{1}$.

Finansyzacja jest rozumiana i definiowana między innymi jako: przejście gospodarki od kapitalizmu przemysłowego do kapitalizmu finansowego ${ }^{2}$, systemowa transformacja dojrzałych gospodarek kapitalistycznych ${ }^{3}$, rosnąca rola motywów finansowych, rynków finansowych, aktorów finansowych i instytucji finansowych w funkcjonowaniu gospodarek krajowych i gospodarki międzynarodowej ${ }^{4}$, zmiana relacji pomiędzy sektorem realnym a sektorem finansowym ${ }^{5}$, tendencja w kierunku czerpania zysków w gospodarce w większym stopniu przez kanały finansowe niż z wykorzystaniem działalności produkcyjnej ${ }^{6}$, czy w końcu jako system redystrybucji dochodów faworyzujący sektor finansowy względem sektora niefinansowego ${ }^{7}$. Również na gruncie krajowej literatury termin finansyzacja lub jego odmiany, takie jak finansjeryzacja czy finansjalizacja, sa definiowane w sposób zróżnicowany. Rzeczone zjawisko jest utożsamiane przez rodzimych autorów między innymi z przerostem sektora finansowego w stosunku do realnego sektora wytwórczego ${ }^{8}$, wzrostem znaczenia motywów finansowych w procesie podejmowania decyzji gospodarczych $^{9}$, autonomizacją sfery finansowej w relacji do sfery realnej ${ }^{10}$, postępująca dominacją sektora finansowego w działalności jednostek gospodarujacych i osób fizycznych ${ }^{11}$, ze znacznym natężeniem skali władzy logiki finansowej w procesach społeczno-gospodarczych ${ }^{12}$ czy też z powszechnym utowarowieniem $\mathrm{dlugu}^{13}$ oraz ze wzrostem znaczenia operacji finansowych

${ }^{1}$ Foster (2007): 2-11; Lapavitsas, Powell (2013): 361; Sawyer (2013): 5. Por. Franc-Dąbrowska (2019): 73.

${ }^{2}$ Van der Zwan (2014): 99-102.

${ }^{3}$ Lapavitsas (2011): 611.

${ }^{4}$ Epstein (2005): 3.

${ }^{5}$ Stockhammer (2010): 2.

${ }^{6}$ Krippner (2011): 4.

7 Tomaskovic-Devey (2015): 389.

${ }^{8}$ Mączyńska (2011): 57. Por. Żyżyński (2010): 27. Zob. Marszałek (2012): 221.

9 Jajuga (2014): 148.

10 Ratajczak (2014): 261.

${ }^{11}$ Kamela-Sowińska (2014): 146. Por. Gostomski (2014): 301. Zob. Rydzewska (2017): 169.

12 Adamczyk (2016): 3.

${ }^{13}$ Sokół (2017): 134. 
w procesie generowania dodatkowej wartości cechujący się częściowym odseparowaniem od sfery realnej ${ }^{14}$.

W literaturze wskazuje się, że termin finansyzacja odnosi się do wielu procesów i praktyk rozpatrywanych w różnej skali oraz różnych okresach, przy czym czasem pojęcie to traktowane jest jako explanandum, innym razem jako explanans, lub wręcz brak jest jasności, jaką funkcje w istocie pojęcie to pełni ${ }^{15}$. Dowodzi się również, że finansyzacja jest pojęciem teoretycznym, w większym stopniu o charakterze asocjacyjnym niż denotacyjnym, za pomoca którego łatwiej naszkicować kompleksowe zmiany ekonomiczne i społeczne, niż precyzyjnie ujać pojedynczą zmianę w zakresie polityki czy tė̇ praktyki gospodarczej ${ }^{16}$.

Zmiany te obejmuja, według Bena Fina, szerokie spektrum zjawisk, do których przywołany autor zalicza: niesłychany rozwój aktywów finansowych w relacji do rzeczywistych procesów gospodarczych, proliferację różnego rodzaju aktywów opartych na pochodnych papierach wartościowych, jak również ekspansję działalności spekulacyjnej odbywającej się w opozycji do działalności zorientowanej na inwestowanie w aktywa trwałe lub też ze szkodą dla niej. W opinii cytowanego autora finansyzacja przejawia się również przesunięciem z działalności produkcyjnej w kierunku imperatywów finansowych w sektorze prywatnym, rosnącymi nierównościami dochodowymi, boomem konsumpcyjnym, który napędzany jest przez działalność kredytowa, a także penetracją przez finanse coraz dalszych obszarów ekonomicznego i społecznego życia związanego z zabezpieczeniem emerytalnym, edukacją i ochroną zdrowia. Ponadto finansyzacja jest utożsamiana z pojawieniem się neoliberalnej kultury polegania na rynkach i prywatnym kapitale, jak również ze związanym z tym antyetatyzmem i wreszcie z utrzymująca się pozycją dolara amerykańskiego $\mathrm{w}$ gospodarce światowej ${ }^{17}$.

W piśmiennictwie prezentowany jest pogląd, że główną cechą charakterystyczną i znakiem rozpoznawczym procesu finansyzacji jest odseparowanie procesu pozyskiwania wartości (value extraction) od procesu tworzenia wartości (value creation). Stało się to możliwe zasadniczo za sprawą upowszechnienia szeregu innowacyjnych i złożonych instrumentów finansowych oraz papierów wartościowych, które bardzo często jedynie w niewielkim stopniu powiązane sa z aktywami bazowymi ${ }^{18}$. W opinii Costasa Lapavitsasa finansyzacja odzwierciedla asymetryczny wzrost akumulacji finansowej w relacji do rzeczywistej akumulacji. Jego zdaniem panujący wcześniej stan równowagi pomiędzy faktyczna akumulacja w gospodarce a akumulacją w wymiarze finansowym uległ zmianie, a dzisiejszy związek pomiędzy systemem finansowym i procesem realnej akumulacji kapitału jest przeciwstawny, kontra-

\footnotetext{
14 Franc-Dąbrowska (2018): 701.

${ }_{15}$ Aalbers (2017): 2.

16 Styhre (2015): 58.

17 Fine (2013): 6.

18 Styhre (2015): 225.
} 
dyktoryjny. Akumulacja finansowa przybiera obecnie formę gromadzenia aktywów finansowych o iluzorycznej wartości ${ }^{19}$.

Reasumując, w literaturze jest dowodzone, że finansyzacja doprowadziła do sytuacji, w której pieniądz nie tylko w różnych jego formach stał się przedmiotem utowarowienia w procesach handlu i wymiany bez odniesienia do realnej gospodarki, lecz także przeniknął niemalże do każdej działalności społecznej, redukujacc działanie w tym obszarze do prostego rachunku ekonomicznego. W rezultacie tego nastapiło podporządkowanie działania podmiotów imperatywom rynków finansowych i instytucji finansowych ${ }^{20}$.

\section{TEO HISTORYCZNE I ETAPY ROZWOJU ZJAWISKA FINANSYZACJI}

Jakkolwiek katalog czynników determinujących rozwój zjawiska finansyzacji jest obszerny, to jednak wydaje się, że kluczowe miejsce zajmuje w nim zmiana paradygmatu w zakresie polityki gospodarczej, jaka nastapiła pod koniec lat siedemdziesiątych XX w., początkowo w USA i Wielkiej Brytanii, później zaś w innych gospodarkach rozwiniętych, jak również rozwijających się. Zgodnie z doktryną neoliberalną przeprowadzona została między innymi deregulacja sektora finansowego, liberalizacja handlu międzynarodowego oraz międzynarodowych przepływów kapitału, wprowadzone zostały elastyczne formy zatrudnienia i wynagrodzenia za pracę, upowszechniona została prywatyzacja i dostosowania strukturalne w gospodarce, nastapiło przesunięcie akcentów z dążenia do pełnego zatrudnienia w kierunku walki z inflacją ograniczeniu uległy obszary oddziaływania państwa. Finansyzacja obok globalizacji została zidentyfikowana jako kluczowy filar, dzięki któremu kapitalizm w skali globalnej mógł się wyzwolić z ograniczeń nałożonych przez zwolenników doktryny keynesistowskiej, która dominowała w okresie powojennym ${ }^{21}$. Finansyzacja gospodarki globalnej stała się jednym z głównym projektów w ramach doktryny neoliberalnej ${ }^{22}$, a sam proces finansyzacji należy postrzegać jako finansowe ramię neoliberalnego paradygmatu ${ }^{23}$. W ramach neoliberalizmu wyjątkowy status uzyskał rynek, który był postrzegany jako pierwszoplanowa i nadrzędna instytucja w procesie koordynacji działań gospodarczych i organizacji społecznej. Szczególne miejsce zajęły rynki finansowe, które były przedstawiane jako doskonale konkurencyjne, efektywne i stabilne oraz zdolnego do odzwierciedlania wszystkich informacji istotnych z ekonomicznego punktu widzenia ${ }^{24}$.

\footnotetext{
19 Lapavitsas (2013): 122, 201-203.

20 Christopherson, Martin, Pollard (2013): 351.

21 Tridico, Pariboni (2018): 238.

22 Tomaskovic-Devey (2015): 382-389.

23 Palley (2013): 60.

24 Palley (2013): 2-4.
} 


\section{Tabela 1}

Uwarunkowania i determinanty rozwoju zjawiska finansyzacji w gospodarce światowej

\begin{tabular}{|c|c|}
\hline $\begin{array}{l}\text { Data i nazwa } \\
\text { czynnika }\end{array}$ & $\begin{array}{c}\text { Skutki w kontekście rozwoju } \\
\text { zjawiska finansyzacji }\end{array}$ \\
\hline $\begin{array}{l}\text { Poczatek lat } 60 . \mathrm{XX} \text { w. } \\
\text { Powstanie rynku eurowalut (eurocur- } \\
\text { rency) }\end{array}$ & $\begin{array}{l}\text { Powstanie ponadnarodowego rynku walutowego poza } \\
\text { jurysdykcją prawną pojedynczych państw. Umożliwie- } \\
\text { nie spekulacji na kursach walutowych i stopach procen- } \\
\text { towych }\end{array}$ \\
\hline $\begin{array}{l}1971 \\
\text { Faktyczny koniec systemu z Bretton } \\
\text { Woods }\end{array}$ & $\begin{array}{l}\text { Wzrost ryzyka związanego z wahaniami kursów walu- } \\
\text { towych, akumulacja rezerw walutowych w skali nieuza- } \\
\text { sadnionej przez dotychczasowe punkty referencyjne, } \\
\text { zwiększenie płynności (prowadzące do nadpłynności) }\end{array}$ \\
\hline $\begin{array}{l}1973,1979-1980 \\
\text { Szoki naftowe }\end{array}$ & $\begin{array}{l}\text { Presja inflacyjna i łagodna odpowiedź ze strony FED } \\
\text { (niska realna stopa procentowa, przejściowo nawet } \\
\text { ujemna) zwiększyły atrakcyjność finansowania dłu- } \\
\text { giem }\end{array}$ \\
\hline $\begin{array}{l}1973 \\
\text { Zaprezentowanie modelu wyceny opcji } \\
\text { metodą Blacka-Scholesa(-Mertona) }\end{array}$ & $\begin{array}{l}\text { Zwiększenie możliwości w zakresie kwantyfikacji } \\
\text { ryzyka oraz umożliwienie tworzenia instrumentów } \\
\text { finansowych }\end{array}$ \\
\hline $\begin{array}{l}\text { Koniec lat } 70 . \mathrm{XX} \text { w. } \\
\text { Powstanie funduszy rynku pieniężnego }\end{array}$ & $\begin{array}{l}\text { Obejście regulacji dotyczących instytucji finansowych } \\
\text { działających w danym kraju. Rozwój krótkotermino- } \\
\text { wego pozagiełdowego rynku pieniężnego oraz instytucji } \\
\text { parabankowych (shadow banking) }\end{array}$ \\
\hline $\begin{array}{l}\text { Przełom lat } 70 . \text { i } 80 . \mathrm{XX} \text { w. } \\
\text { Początek dynamicznego rozwoju instru- } \\
\text { mentów pochodnych }\end{array}$ & $\begin{array}{l}\text { Stworzenie rynku instrumentów zabezpieczających } \\
\text { przed ryzykiem, umożliwienie spekulacji, przy mini- } \\
\text { malnym zaangażowaniu kapitałowym }\end{array}$ \\
\hline $\begin{array}{l}\text { 1980-1984 } \\
\text { Podniesienie stóp procentowych (Volker } \\
\text { shocks) }\end{array}$ & $\begin{array}{l}\text { Nagły wzrost realnych stóp procentowych, zwiększe- } \\
\text { nie atrakcyjności rynku amerykańskiego i napływ } \\
\text { kapitału spekulacyjnego, który finansował wykupy } \\
\text { lewarowane oraz napędzał powstawanie bańki spe- } \\
\text { kulacyjnej }\end{array}$ \\
\hline $\begin{array}{l}1989 \\
\text { Upadek muru berlińskiego }\end{array}$ & $\begin{array}{l}\text { Proces transformacji gospodarek socjalistycznych } \\
\text { w kierunku wolnego rynku, pojawienie się nowych ryn- } \\
\text { ków wschodzących }\end{array}$ \\
\hline $\begin{array}{l}1988 \\
\text { Przyjęcie Umowy kapitałowej opraco- } \\
\text { wanej przez Bazylejski Komitet Nadzo- } \\
\text { ru Bankowego (Basel I) }\end{array}$ & $\begin{array}{l}\text { Wzrost popytu ze strony banków komercyjnych na } \\
\text { papiery wartościowe o wysokim ratingu }\end{array}$ \\
\hline $\begin{array}{l}\text { Koniec lat } 90 . \mathrm{XX} \text { w. } \\
\text { Początek wdrażania niekonwencjonal- } \\
\text { nej polityki monetarnej przez Bank Ja- } \\
\text { ponii }\end{array}$ & $\begin{array}{l}\text { Zwiększenie dostępności kapitału dla instytucji fi- } \\
\text { nansowych, obniżenie rentowności inwestowania na } \\
\text { rynku pieniężnym. Wzrost popytu na aktywa finan- } \\
\text { sowe, zwiększenie możliwości stosowania wyższej } \\
\text { dźwigni finansowej }\end{array}$ \\
\hline $\begin{array}{l}2007- \\
\text { Początek kryzysu finansowego w Sta- } \\
\text { nach Zjednoczonych }\end{array}$ & $\begin{array}{l}\text { Bezprecedensowe działania zmierzające do rato- } \\
\text { wania kluczowych instytucji finansowych w wielu } \\
\text { krajach dotkniętych kryzysem. Uspołecznienie strat } \\
\text { poniesionych przez instytucje finansowe, urzeczy- } \\
\text { wistnienie koncepcji too big to fail }\end{array}$ \\
\hline
\end{tabular}

Źródło: Urban (2019): 56-57. 
Rynek finansowy przez zwolenników neoliberalizmu przedstawiany był powszechnie jako najbardziej efektywny i najlepiej działający ze wszystkich rynków, który nie tylko sam w sobie jest zdolny do tworzenia bogactwa w sensie ekonomicznym, lecz także posiada zdolność dyscyplinowania oraz monitorowania pozostałych rynków ${ }^{25}$. Katalog wybranych determinant zjawiska finansyzacji zaprezentowano w tabeli 1 .

Elementem łączącym większość opracowań naukowych poświęconych finansyzacji jest twierdzenie i opinia, że genezę zjawiska finansyzacji dostrzec można pod koniec lat siedemdziesiątych lub też na początku lat osiemdziesiątych ubiegłego wieku. Na tym tle wyjątkowy jest pogląd prezentowany przez niektórych autorów, według których finansyzacja jest zjawiskiem powracającym i powtarzającym się, a obecnie obserwować można kolejny etap tego procesu. Alessandro Vercelli przekonuje, że pierwsza fala finansyzacji nastapiła w latach 1880-1929, druga zaś rozpoczęła się w latach osiemdziesiątych ubiegłego wieku i trwa po dziś dzień. W opinii cytowanego autora pierwszy etap finansyzacji na opierał się głównie na systemie bankowym, a także charakteryzował go ograniczony wpływ lub też brak wpływ ze strony banku centralnego. Z kolei na jej drugim etapie kluczową rolę pełnią rynki finansowe, bank centralny zaś pełni tutaj istotną funkcję $e^{26}$.

Tabela 2

Fazy finansyzacji w gospodarce amerykańskiej

\begin{tabular}{|l|l|l|l|l|}
\hline \multicolumn{1}{|c|}{$\begin{array}{c}\text { Etapy procesu } \\
\text { finansyzacji } \\
\text { w gospodarce } \\
\begin{array}{c}\text { Stanów } \\
\text { Zjednoczonych }\end{array}\end{array}$} & \multicolumn{1}{|c|}{$\begin{array}{c}\text { Okres 1 } \\
\mathbf{( 1 9 0 0 - 1 9 3 3 )}\end{array}$} & $\begin{array}{c}\text { Okres 2 } \\
\mathbf{( 1 9 3 4 - 1 9 4 0 )}\end{array}$ & $\begin{array}{c}\text { Okres 3 } \\
\mathbf{( 1 9 4 5 - 1 9 7 3 )}\end{array}$ & $\begin{array}{c}\text { Okres 4 } \\
\mathbf{( 1 9 7 4 - 2 0 1 0 )}\end{array}$ \\
\hline $\begin{array}{l}\text { Dominacja sektora } \\
\text { finansowego }\end{array}$ & Tak & - & Nie & Tak \\
\hline $\begin{array}{l}\text { Udział dochodów sekto- } \\
\text { ra finansowego }\end{array}$ & $\begin{array}{l}\text { Umiarkowanie } \\
\text { wysoki }\end{array}$ & $\begin{array}{l}\text { Umiarkowanie } \\
\text { niski }\end{array}$ & $\begin{array}{l}\text { Umiarkowanie } \\
\text { niski }\end{array}$ & Wysoki \\
\hline Regulacje finansowe & Nie & Tak & Tak & Nie \\
\hline $\begin{array}{l}\text { Orientacja na wartość } \\
\text { dla akcjonariuszy }\end{array}$ & Tak & Nie & Tak \\
\hline $\begin{array}{l}\text { Intensywność innowacji } \\
\text { finansowych }\end{array}$ & Umiarkowana & Umiarkowana & Wysoka & Wysoka \\
\hline $\begin{array}{l}\text { Zadłużenie gospodarstw } \\
\text { domowych }\end{array}$ & $\begin{array}{l}\text { Umiarkowanie } \\
\text { wysokie }\end{array}$ & Niskie & Umiarkowane & Wysokie \\
\hline Nierówności dochodowe & Wysokie & Niskie & Niskie & Wysokie \\
\hline $\begin{array}{l}\text { Dażenie do pełnego } \\
\text { zatrudnienia }\end{array}$ & Nie & Tak & Tak & Nie \\
\hline
\end{tabular}

${ }^{25}$ Styhre 2015: 60

${ }^{26}$ Vercelli (2017): 103-107. 


\begin{tabular}{|l|l|l|l|l|}
\hline $\begin{array}{l}\text { Sterowanie niską } \\
\text { inflacją }\end{array}$ & - & - & Nie & Tak \\
\hline $\begin{array}{l}\text { Dźwignia finansowa } \\
\text { i skłonność do kryzysów } \\
\text { finansowych }\end{array}$ & Wysokie & Niskie & Niskie & Wysokie \\
\hline
\end{tabular}

Źródło: Pasianos, Guevara, Pierros (2016): 30.

O krok dalej, jeśli chodzi o wyodrębnianie etapów rozwoju zjawiska finansyzacji, idą Apostolos Fasianos, Diego Guevera i Christos Perros ${ }^{27}$. Dowodza oni mianowicie, że w odniesieniu do gospodarki amerykańskiej, w której proces finansyzacji został zapoczątkowany i osiagnął najbardziej zaawansowane stadium, wyróżnić można cztery okresy finansyzacji, co ukazane zostało w tabeli 2. Początek ostatniego etapu rozwoju zjawiska finansyzacji w gospodarce amerykańskiej jest równocześnie wskazywany jako moment zapoczątkowania procesów finansyzacji w gospodarce światowej.

\section{MAKROEKONOMICZNE ASPEKTY FINANSYZACJI}

Analiza literatury przedmiotu daje podstawy, by zjawisko finansyzacji łączyć co najmniej z trzema aspektami makroekonomicznymi: po pierwsze, z przekształceniami na wybranych rynkach towarowych; po drugie, ze zmiana roli państwa i podporządkowaniem polityki gospodarczej jednemu celowi polityki monetarnej, i wreszcie po trzecie, by analizować je w kontekście zjawisk makroekonomicznych, które finansyzacji towarzysza.

Jeśli chodzi o pierwszy aspekt, to $\mathrm{w}$ piśmiennictwie prezentowany jest pogląd, że w okresie finansyzacji diametralnej zmianie uległy giełdy towarowe. Rynki, na których dominująca pozycję miały wcześniej podmioty z realnej sfery gospodarki (takie jak: rafinerie, kopalnie, gospodarstwa domowe, rynki towarowe), przeistoczyły się w rynki podmiotów finansowych: funduszy hedgingowych, Exchange Traded Funds, jak również portfeli managedfutures. Towarzyszyły temu głębokie i strukturalne zmiany, które objawiały się skłonnościami do generowania baniek cenowych, wzrostem korelacji pomiędzy surowcami i innymi klasami aktywów, jak również zmianami w strukturze terminowej rynku określonych aktywów ${ }^{28}$. Ceny poszczególnych aktywów na rynkach towarowych przestały być kształtowane przez tradycyjne czynniki popytowo-podażowe, stały się natomiast podatne na agregatowy poziom skłonności do ponoszenia ryzyka akceptowany i preferowany przez inwestorów finansowych w procesie konstruowania portfeli inwestycyjnych ${ }^{29}$. Ponadto finansyzacja rynków towarowych doprowadziła do pojawienia się zjawiska,

\footnotetext{
27 Pasianos, Guevara, Pierros (2016): 30.

28 Zaremba (2014): 243.

29 Tomaszewski (2015): 606.
} 
o którym można z teoretycznego punktu widzenia powiedzieć, że generuje ono proces swoistej deformacji informacyjnej funkcji ceny światowej. Wynika to z tego, że popyt zgłaszany przez inwestorów finansowych jest zasadniczo wyrazem zapotrzebowania na aktywa finansowe bazujące na towarach, nie zaś odzwierciedleniem rzeczywistego popytu na towary, zgłaszanego przez realną sferę gospodarki i będącego pochodna obecnej i oczekiwanej koniunktury gospodarczej. W rezultacie cena kształtowana na rynkach towarowych nie dostarcza już podmiotom gospodarczym z realnego sektora właściwych i użytecznych informacji pozwalajacych podejmować adekwatne działania (np. $\mathrm{w}$ odniesieniu do zmiany wielkości produkcji i zapasów) ${ }^{30}$. W literaturze dowodzi się również, że zmiany na rynkach towarowych były rezultatem odkrycia przez inwestorów negatywnej korelacji pomiędzy stopami zwrotu uzyskiwanymi na rynkach towarowych a stopami zwrotu osiaganymi na rynku akcyjnym. Konsekwencją tego było stworzenie i upowszechnienie całego szeregu derywatów na rynkach towarowych, które przedstawiane były jako nowa klasa racjonalnych inwestycji, umożliwiająca redukcję ryzyka portfelowego. W efekcie te nowe instrumenty finansowe stały się przedmiotem masowego popytu zgłaszanego zarówno przez inwestorów instytucjonalnych, jak i inwestorów indywidualnych, a rosnąca obecność inwestorów zainicjowała proces tzw. finansyzacji na rynkach towarowych. Jego skutkiem w opinii niektórych autorów było zwiększenie korelacji cen na rynkach towarowych z cenami aktywów finansowych, a także korelacji w obrębie cen samych towarów ${ }^{31}$. Rozwój derywatów i kontraktów na różnice doprowadził do sytuacji, w której tradycyjne rynki towarowe zostały zepchnięte na drugi plan, czego dowodem jest wykorzystywanie obecnie do analiz cen surowców niemalże wyłącznie cen transakcji zawieranych na rynkach terminowych, nie zaś cen transakcji rzeczywistych ${ }^{32}$.

Szczególnym przykładem finansyzacji rynku, wskazywanym i relatywnie często w sposób szczegóły omawianym, jest rynek ropy naftowej. Dowodzi się między innymi, że za sprawą instrumentów pochodnych ropa naftowa stała się $\mathrm{w}$ większym stopniu przedmiotem handlu nie jako surowiec, lecz jako rodzaj aktywów finansowych, którymi obrót odbywa się w sposób niezależny od rynku rzeczywistych transakcji skutkujących fizyczną dostawą towaru. Instrumenty pochodne oparte na ropie naftowej przekształcone zostały w odrębną klasę aktywów, która jest postrzega przez inwestorów jako kolejny rodzaj aktywów finansowych, uwzględnianych w procesie budowania portfeli inwestycyjnych ${ }^{33}$. Podkreśla się, że na cenę surowca w sposób znaczący wpływa spekulacja z wykorzystaniem kontraktów futures, a obrót towarowymi instrumentami pochodnymi na ropę kilkunastokrotnie przewyższa rzeczywiste transakcje fizycznej sprzedaży i zakupu ropy zawierane na rynku ${ }^{34}$. Badania empiryczne wskazuja również, że finansyzacja rynku ropy naftowej doprowadziła do głębokim zmian przejawiających się między innymi większymi wahaniami cen na rynku trans-

\footnotetext{
${ }^{30}$ Dudziński (2013): 231-232.

31 Falkowski (2011): 6. Por. Aspadarec (2013): 32-33.

32 Fierla (2017): 41.

33 Gkanoutas-Leventis (2017): 123-124.

${ }^{34}$ Gkanoutas-Leventis, Nesvetailova (2015): 894; Falkowski (2011): 6.
} 
akcji spot, wzrostem powiązania zmian cen ropy naftowej z cenami aktywów finansowych, jak również wpływem strategii i preferencji inwestorów finansowych na kształtowanie się cen ropy naftowej na rynku terminowym ${ }^{35}$.

Drugim makroekonomicznym aspektem związanym z procesami finansyzacji gospodarki jest przekształcenie w zakresie funkcji pełnionej przez państwo i roli polityki banku centralnego. John Foster przekonuje, że pod koniec lat osiemdziesiątych ubiegłego wieku tradycyjna struktura gospodarki, w której system produkcyjny obsługiwany był przez niewielki i podległy system finansowy, zastapiona została przez nową strukturę, w której znacząco rozwinięty sektor finansowy uzyskał wysoki poziom niezależności i stał się dominujacy w relacji do systemu produkcyjnego. W rezultacie doprowadziło to do impasu gospodarczego przejawiajacego się: stagnacją w gospodarce kapitalistycznej i większym uzależnieniem od sfery finansowej, powstaniem finansowej struktury niezdolnej do rozwoju w sposób całkowicie niezależny od realnej gospodarki oraz brakiem możliwości przezwyciężenia stagnacji w sektorze produkcyjnym przez rozszerzanie procesu finansyzacji. Jak dowodzi cytowany autor, w celu sprostania nowym imperatywom finansyzacji przekształcona została rola państwa w gospodarce kapitalistycznej. W pełni przyjęto zasadę zakładającą pełnienie przez państwo roli pożyczkodawcy ostatniej instancji, który odpowiedzialny jest za natychmiastowe dostarczanie płynności do systemu finansowego, jak również urzeczywistniona została koncepcja too big to fail ${ }^{36}$.

Przekształceniu uległa również polityka monetarna realizowana przez banki centralne, w ramach której głównym celem stało się zapewnienie stabilności cen, czego odzwierciedleniem stał się triumf koncepcji inflation-targeting. Polityka zakładająca sterowanie inflacją przekształcona została w dominujący paradygmat, któremu podporządkowane zostało prowadzenie polityki monetarnej przez wiele banków centralnych zarówno z krajów rozwiniętych, jak i rozwijajacych się. Ponadto tak definiowany cel polityki monetarnej realizowany był w sposób pośredni lub też nieformalny przez ustanowienie maksymalnego poziomu dopuszczalnej i pożądanej inflacji (inflation-caps) przez kilkanaście kolejnych banków centralnych. Działo się tak przez ponad dwie dekady, mimo że w literaturze przedmiotu podawano w wątpliwość faktyczna efektywność takiej polityki. Polityka monetarna ukierunkowana na sterowanie inflacją zakładała i implikowała konieczność podporządkowania jej innych celów realizowanych w ramach polityki gospodarczej (wśród nich m.in.: tworzenia miejsce pracy, wzrostu gospodarczego jak również dystrybucji dochodów). Sterowanie inflacją zdeterminowało i zdominowało niemalże na dwie dekady kierunki i charakter polityki gospodarczej prowadzonej przez wiele krajów na świecie ${ }^{37}$.

Jak przekonuje Demophanes Papadotos, dzięki niezależności banku centralnego polityka monetarna ukierunkowana została na dostarczenie insty-

${ }^{35}$ Tang, Xiong (2012): 54-57; Żelazny (2016): 34-42; Singelton (2014): 300-318; Etula (2013): $486-521$.

${ }^{36}$ Foster (2007): 6-7.

37 Papadatos (2012): 120-127; Arestis, Sawyer (2004): 1-31. 
tucjonalnego zapewnienia dla sektora finansowego, że inflacja jako zjawisko szczególnie negatywne z punktu widzenia tego sektora nie będzie tolerowane i pobłażane. Ponadto w opinii przedstawicieli banków centralnych bańki spekulacyjne prezentowane były jako zjawisko nieistotne z punktu widzenia celów oraz zadań bankowości centralnej, a ich wystapienie jako mało prawdopodobne, jeśli tylko utrzymywany będzie niski poziom inflacji. W rezultacie zdaniem przywołanego autora sektor finansowy został ugruntowany $\mathrm{w}$ przekonaniu, że bank centralny nie będzie podejmował interwencji podczas spekulacji prowadzonych przez instytucje finansowe, których konsekwencja będzie oderwanie się cen od wartości fundamentalnych w wybranych segmentach rynku, a równocześnie zapewniał będzie ochronę przed wysoką inflacją i negatywnymi konsekwencjami dotykajacymi instytucje finansowe. Przyjęto również, że koszty związane z pęknięciem bańki spekulacyjnej przerzucone zostaną na społeczeństwo. W istocie więc wraz z upływem czasu polityka sterowania inflacja przyjmowała za cel ochronę prywatnych zysków podczas bańki spekulacyjnej i uspołecznienie kosztów jej pęknięcia.

Ostatni kryzys finansowy podważył to, co stanowiło największe osiagnięcie polityki monetarnej w ramach sterowania inflacja, a mianowicie wiarygodność banku centralnego ${ }^{38}$. Z kolei Adair Turner przekonuje, że w okresie ostatnich 30 lat (czyli de facto w okresie rozwoju zjawiska finansyzacji) banki centralne krajów rozwiniętych zarzuciły kontrolę nad całkowitą wielkościa kredytu kreowanego przez sektor prywatny, jak również sposobem jego alokacji w gospodarce. Koncentrowały się one natomiast na kwestii stabilności oraz wypłacalności samego sektora finansowego. Polityka monetarna oparta na przekonaniu, że dopóki inflacja pozostaje na niskim i stabilnym poziomie, dopóty suma kredytu i pieniądza kreowanego przez sektor prywatny pozostaje na właściwym poziomie, zaowocowała okresem wielkiego umiarkowania. Zakończył się on gospodarczą katastrofą w postaci ostatniego kryzysu finansowego, ponieważ gwałtowny wzrost kredytu doprowadził do nadmiernego zadłużenia ${ }^{39}$. Polityka monetarna ukierunkowana na sterowanie inflacja oraz koncepcja niezależności banku centralnego ułatwiają obecnie czerpanie prywatnych zysków, za cenę niestabilności finansowej oraz strat ponoszonych przez społeczeństwo ${ }^{40}$.

Trzecią kwestią podejmowaną na poziomie makroekonomicznym pozostaja zjawiska ekonomiczne łączone z procesem finansyzacji. W tej grupie wymienia się między innymi: zwiększona częstotliwość zjawisk kryzysowych w gospodarce, narastajaccy problem zadłużenia oraz negatywne oddziaływanie nadmiernie rozwiniętego sektor finansowego na wzrost gospodarczy, jak również zjawisko inflacji aktywów. Jeśli chodzi o pierwsze z wymienionych zjawisk, wskazać należy, że finansyzacja gospodarki jest łączona ze zwiększona podatnością tej ostatniej na kryzysy. Autorzy przekonuja, że w ostatnich 30 latach kryzysy finansowe były bardziej rozległe i powszechniejsze niż w każdym

\footnotetext{
38 Papadotos (2012): 133-139.

39 Turner (2016): 109.

40 Papadotos (2012): 140-141.
} 
innym okresie ${ }^{41}$. Dowodzi się również, że poczynając od roku 1971, kryzysy stały się dużo częstszym zjawiskiem ekonomicznym, a prawdopodobieństwo ich wystapienia oszacowane zostało na $4 \% \mathrm{w}$ skali roku ${ }^{42}$. W literaturze przedmiotu dokonano identyfikacji 147 kryzysów bankowych, 218 kryzysów walutowych oraz 67 kryzysów zadłużenia, które wystapiły w latach 1970-2012 $2^{43}$, jak również opisano 153 epizody kryzysów bankowych, które wystapiły w latach 1980-2010, zestawiajac je z 2 przypadkami z lat 1945-1970 oraz 9 przypadkami z lat 1970-198044. W piśmiennictwie prezentuje się pogląd, że skala i zakres kryzysów finansowych, które wystapiły w okresie dominacji rynkowego paradygmatu w polityce gospodarczej, sa przytłaczające i olbrzymie w porównaniu z powojennym okresem dominacji doktryny keynesistowskiej ${ }^{45}$.

Zjawisko finansyzacji gospodarki łączone jest również z zadłużeniem, długiem generowanym zarówno na poziomie państw, korporacji, jak i długiem gospodarstw domowych, którego tworzenie w procesie finansyzacji zostało znacząco ułatwione. Wskazuje się, że zestawienie agregatowego poziomu zadłużenia z wielkością produkcji i kapitału w gospodarce globalnej przypomina kształtem odwróconą piramidę. Olbrzymi nagromadzony dług opiera się na niewielkiej bazie tworzonej przez rzeczywistą produkcję dóbr i usług w realnej gospodarce, która zmuszona jest generować strumień zysków niezbędnych do obsługi zadłużenia. Wzrost zadłużenia niemalże przeciął związek pomiędzy finansami a realną sferą gospodarki. Dowodzi się ponadto, że współczesne przepływy kapitału w wielu przypadkach przestały odgrywać pozytywną rolę narzędzia efektywnej alokacji kapitału w skali globalnej, jaka przypisywana jest im przez teorię ekonomii. Zamiast tego przepływy te powiększają wielkość tworzonego w niezrównoważonym stopniu długu i powodują efekty nawisu długu w okresach pokryzysowych ${ }^{46}$.

W odniesieniu do kwestii oddziaływania finansyzacji na wzrost gospodarczy wskazuje się, że brak dowodów empirycznych potwierdzających, iż gospodarki krajów rozwiniętych w następstwie procesów zwiększających rolę sektora finansowego stały się bardziej efektywne, odnotowały wyższe stopy wzrostu gospodarczego ${ }^{47}$. Jest wręcz odwrotnie. Prezentowane są wyniki badań empirycznych prowadzące do konstatacji, że krańcowy wpływ głębokości finansowej na wzrost produkcji staje się negatywny, gdy wielkość kredytu kierowanego przez system finansowy do sektora prywatnego osiaga przedział $80-100 \%$ produktu krajowego brutto. Jest to jednocześnie poziom wskazywany jako ten, po którego przekroczeniu głębokość finansowa zaczyna zwiększać amplitudę wahań w obszarze wzrostu gospodarczego. W opinii innych autorów z punktu widzenia wzrostu gospodarczego efekt głębokości finansowej ma charakter za-

\footnotetext{
${ }^{41}$ Kindelberger, Aliber (2005).

42 Schularick, Taylor (2012): 9.

${ }^{43}$ Laeven, Valencia (2016).

${ }^{44}$ Reinhart, Rogoff (2009).

45 Malvey (2017): 11.

46 Askari, Mirakhor (2015): 12; Turner (2016): 152.

${ }^{47}$ Turner (2016): 89.
} 
nikający, a wiele krajów osiągnęło lub przekroczyło punkt, od którego rozwój sektora finansowego wywiera negatywny wpływ na wzrost gospodarczy ${ }^{48}$.

W piśmiennictwie prezentowany jest również pogląd, zgodnie z którym finansyzacja pozostaje $\mathrm{w}$ bezpośrednim związku ze zjawiskiem inflacji aktywów na rynkach kapitałowych. Dzieje się tak w następstwie recyrkulacji zysków z wykorzystaniem rynków kapitałowych, w którym to procesie gwałtowny wzrost popytu na aktywa finansowe prowadzi do wzrostu cen tychże aktywów. Napływ kapitału na rynek kapitałowy, przewyższajacy aktualne potrzeby podmiotów gospodarczych, skutkuje zdaniem niektórych autorów wzrostem cen i wzrostem obrotu aktywami, ten wyższy obrót aktywami oznacza zaś ich większą płynność. Może to prowadzić do samonapędzającego się procesu dalszego zwiększania aktywów o charakterystykach zbliżonych do pieniądza. W rezultacie możliwy staje się wzrost płynności rynkowej tak, jakby była ona następstwem zwiększenia podaży pieniądza w gospodarce ${ }^{49}$. Jan Toporowski przekonuje, że w sytuacji gdy proces inflacji aktywów na rynkach kapitałowych ulega osłabieniu, celem funkcjonowania rynków przestaje być instytucjonalna służba na rzecz pozostałej części gospodarki, natomiast staje się nim zapewnienie dalszego napływu kapitału. W konsekwencji rozwój gospodarczy staje się jedynie ubocznym i dodatkowym produktem funkcjonowania rynku kapitałowego ${ }^{50}$.

Dowodzone jest również, że wyższy poziom płynności aktywów na rynku oraz wzrost skali podejmowanych działań spekulacyjnych generują poważne efekty zewnętrzne z punktu widzenia przedsiębiorstw w realnym sektorze gospodarki i potrzeb gospodarki jako całości. Wygórowane i nadmierne zyski kapitałowe uzyskiwane przez stosowanie dźwigni finansowej pomniejszają bowiem relatywne stopy zwrotu możliwe do osiagnięcia za sprawą projektów inwestycyjnych realizowanych w realnej sferze gospodarki. Rezultatem tego jest pojawienie się swoistego efektu wysysania, któremu podlega nie tylko kapitał niewykorzystywany w realnym sektorze gospodarki i transferowany do sektora finansowego. Dotyczy to również kapitału, który mógłby być wykorzystany $\mathrm{w}$ realnych sektorach gospodarki, lecz zostaje przyciagnięty przez obietnicę niewspółmiernych zysków i przejęty przez sektor finansowy ${ }^{51}$.

\section{ZAKOŃCZENIE}

W dyskursie akademickim coraz częściej prezentowane sa opinie, że w następstwie finansyzacji w najwyżej rozwiniętych krajach świata zachodniego nastapiła ewolucja kapitalizmu przemysłowego, który przekształcił się w kapitalizm finansowy. W modelu tym za siłę i znaczenie gospodarki w dużo mniejszym

${ }^{48}$ Arcand, Berkes, Panizza (2012): 5-6; Easterly, Islam, Stiglitz (2000); Rousseau, Wachtel (2011): 276-288; Panizza (2012): 155. Zob. Ratajczak (2017): 32-33.

${ }^{49}$ Lucarelli (2012): 431; Nesvetailova (2005): 401; Toporowski (2000): 57.

${ }^{50}$ Toporowski (2000): 131.

${ }^{51}$ Woo (2017): 47. 
stopniu odpowiadają podmioty wywodzące się z realnych sektorów gospodarki, natomiast coraz większe znaczenie odgrywają instytucje finansowe, a także działalność finansowa. Doświadczenia związane z ostatnim kryzysem finansowym, jak również obecna kondycja gospodarek krajów zachodnich stanowić mogą podstawę do konkluzji, że być może finansyzacja nie zwiększa możliwości konkurowania kapitalizmu finansowego z kapitalizmem państwowym, który to model wdrażany jest z powodzeniem w krajach azjatyckich. Ze wszech miar słuszne i racjonalne zdaje się zatem przeprowadzenie pogłębionych rozważań na temat zasadności i ewentualnej konieczności przeprowadzenia procesu definansyzacji gospodarki, zmierzającego do przywrócenia ugruntowanej historycznie roli sektora finansowego. Z drugiej strony w przypadku krajów o niskim poziomie i natężeniu zjawiska finansyzacji gospodarki konieczne wydaje się podjęcie debaty na temat pożądanych kierunków rozwoju sektora finansowego. Dyskusja taka oparta winna być na trzeźwym i pragmatycznym spojrzeniu, jak również merytorycznej i chłodnej kalkulacji, jakie wzorce rozwoju można powielać, a implementacji jakich rozwiązań należy unikać.

\section{Dariusz Urban}

Uniwersytet Łódzki

dariusz.urban@uni.lodz.pl

https://orcid.org/0000-0003-0500-1830

Aalbers, M. (2017). Corporate financialization, [w:] D. Richardson, N. Castree, M. Goodchild, A. Kobayashi, W. Liu, R. Marston (eds.), International Encyclopedia of Geography. John Wiley \& Sons Ltd.: $1-11$.

Adamczyk, P. (2016). Finansyzacja przedsiębiorstwa jako czynnik jego alienacji od sfery realnej. Autoreferat rozprawy doktorskiej napisanej pod kierunkiem naukowym prof. SGH dr hab. Marii Aluchny (Maszynopis). SGH. Warszawa.

Arcand, J.-L., Berkes, E., Panizza, U. (2012). Too much finance? IMF Working Paper, 12/161: $1-50$.

Arestis, P., Sawyer, M. (2004). Inflation targeting: a critical appraisal. The Levy Economics Institute and University of Leeds, 388: 1-31.

Askari, H., Mirakhor, A. (2015). The Next Financial Crisis and How to Save Capitalism. Palgrave Macmillan.

Aspadarec, W. (2013). Kryzys finansowy a finansyzacja rynków towarowych. Management and Business Administration. Central Europe 2: 23-37.

Christopherson, S., Martin, R., Pollard, J. (2013). Financialisation: roots and repercussions. Cambridge Journal of Regions, Economy and Society 6: 351-357.

Dudziński, J. (2013). Uwagi o działalności inwestorów finansowych na rynkach towarowych. Prace Naukowe Uniwersytetu Ekonomicznego we Wrocławiu 315: 223-233.

Easterly, W., Islam, R., Stiglitz, J. (2000). Shaken and Stirred: Explaining Growth Volatility, Annual Bank Conference on Development Economics, World Bank, Washington, D.C.

Epstein, G. (ed.) (2005). Financialization and the World Economy. Cheltenham: Edward Elgar.

Etula, E. (2013). Broker-dealer risk appetite and commodity returns. Journal of Financial Econometrics 11(3): 486-521.

Falkowski, M. (2011). Financialization of commodities. Contemporary Economics 5(4): 4-17.

Fierla, A. (red.) (2017). Finansjeryzacja gospodarki i jej wpływ na przedsiębiorstwa. Warszawa: Oficyna Wydawnicza SGH.

Fine, B. (2013). Towards a material culture of financialisation. FESSUD Working Paper Series, 15: $1-55$.

Foster, J. (2007). The Financialization of Capitalism. Monthly Review 58(1): 1-12. 
Franc-Dąbrowska, J. (2018). Ufinansowienie gospodarki i finansowy wzrost wartości. Ekonomista 6: 701-718.

Franc-Dąbrowska, J. (2019). Financialization and speculation in agriculture - positive and negative aspects of the financialization of the economy. Annals of the Polish Association of Agricultural and Agribusiness Economists 21(3): 73-81.

Gostomski, E. (2014). Finansyzacja w gospodarce światowej. Biznes Międzynarodowy w Gospodarce Globalnej 33: 299-311.

Gkanoutas-Leventis, A. (2017). Spikes and Shocks. The Financialisation of the Oil Market from 1980 to the Present Day. London: Palgrave Macmillan.

Gkanoutas-Leventis, A., Nesvetailova, A. (2015). Financialisation, oil and the Great Recession. Energy Policy 86: 891-902.

Jajuga, K. (2014). W poszukiwaniu miar ryzyka finansowego, [w:] J. Czekaj, S. Owsiak (red.), Finanse w rozwoju gospodarczym i społecznym. Warszawa: PWE: 147-157.

Kamela-Sowińska, A. (2014). Finansyzacja gospodarki wyzwaniem dla rachunkowości. Prace Naukowe Uniwersytetu Ekonomicznego we Wrocławiu 329: 145-151.

Kindelberger C., Aliber, R. (2005). Manias, Panics and Crashes: A History of Financial Crisis. Hoboke: John Wiley and Sons.

Krippner, G. (2011). Capitalizing on Crisis: The Political Origins of the Rise of Finance. Cambridge: Harvard University Press.

Laeven, L., Valencia, F. (2016). Systemic Banking Crisis Database: An Update. IMF Working Paper, 12/163: 1-33.

Lapavitsas, C. (2011). Theorizing financialization. Work, Employment and Society 25(4): 611-626.

Lapavitsas, C. (2013). Profiting Without Producing. How Finance Exploits Us All. London: Verso.

Lapavitsas, C., Powell, J. (2013). Financialisation varied: a comparative analysis of advanced economies. Cambridge Journal of Regions, Economy and Society 6: 359-379.

Lucarelli, B. (2012). Financialization and Global Imbalances: Prelude to Crisis. Review of Radical Political Economics 44(4): 429-447.

Malvey, J. (2017). The early 21-st century evolution of global capital markets: the great transition era, [w:] G. Strumeyer, S. Swammy (eds.), The Capital Markets. Evolution of the Financial Ecosystem. New Jersey: Wiley and Sons.

Marszałek, P. (2012). Finansyzacja - problemy i kontrowersje. Prace Naukowe Uniwersytetu Ekonomicznego we Wrocławiu 247: 220-230.

Mączyńska, E. (2011). Dysfunkcje gospodarki w kontekście ekonomii kryzysu. Zeszyty Naukowe Polskiego Towarzystwa Ekonomicznego 9: 43-70.

Nesvetailova, A. (2005). United in debt: towards a global crisis of debt-driven finance? Science and Society 69(3): 396-419.

Palley, T. (2013). Financialization. The Economics of Finance Capital Domination. Palgrave Macmillan.

Panizza, U. (2012). Finance and economic development, [w:] G. Carbonier (ed.), International Development Policy: Aid, Emerging Economies and Global Policies. Geneva: Palgrave Macmillan.

Papadatos, D. (2012). Central banking in contemporary capitalism: inflation - targeting and financial crisis, [w:] C. Lapavitsas (ed.), Financialisation in Crisis, Historical Materialism Book Series. Leiden-Boston: Brill.

Pasianos, A., Guevara, D., Pierros, C. (2016). Have we been here before? Phases of financialization within the $20^{\text {th }}$ century in the United States. Levy Economics Institute of Bard Colleges, Working Paper 869.

Ratajczak, M. (2014). Ekonomia w dobie finansyzacji gospodarki. Ruch Prawniczy, Ekonomiczny i Socjologiczny 76(2): 259-270.

Ratajczak, M. (2017). Wzrost gospodarczy w warunkach finansyzacji gospodarki. Studia Oeconomica Posnaniensia 5(5): 23 -37.

Reinhart, C., Rogoff, K. (2009). This Time Is Different: Eight Centuries of Financial Folly. Princeton: Princeton University Press.

Rousseau, P., Wachtel, P. (2011). What is happening to the Impact of financial deepening on economic growth? Economic Inquiry 49(1): 276-288.

Rydzewska, A. (2017). Finansjalizacja a klasyczne funkcje giełdy papierów wartościowych. Studia i Prace Kolegium Zarządzania i Finansów SGH 154: 155-172. 
Sawyer, M. (2013). What is financialization? International Journal of Political Economy: A Journal of Translations 42(4): 5-18.

Schularick, M., Taylor, M. (2012). Credit booms gone bust: monetary policy leverage cycles and financial crisis, 1870-2008. American Economic Review 102(4): 1029-1061.

Singelton, K. (2014). Investor flows and the 2008 boom/ bust oil prices. Management Science 60(2): 300-318.

Sokół, H. (2017). Krótkoterminowe papiery dłużne w zarządzaniu płynnością przedsiębiorstwa, [w:] A. Fierla (red.), Finansjeryzacja gospodarki i jej wpływ na przedsiębiorstwa. Warszawa: Oficyna Wydawnicza SGH: 134-172.

Stockhammer, E. (2010). Financialization and the global economy. University of Massachusetts Working Paper, 240: 1-18.

Styhre, A. (2015). The Financialization of the Firm. Managerial and Social Implications. Cheltenham: Edward Elgar Publishing.

Tang, K., Xiong, W. (2012). Index investment and financialization of commodities. Financial Analyst Journal 68(6): 54-74.

Tomaskovic-Devey, D. (2015). Beware financialization, attractive and dangerous, but mostly dangerous. Teorija in Praksa 52(3): 382-393.

Tomaszewski, J. (2015). Finansjalizacja a zmiany strukturalne na rynku towarów rolnych w pierwszych latach XXI wieku. Annales Universitatis Mariae Curie-Skłodowska, Sectio H, 4: $601-610$.

Toporowski, J. (2000). The End of Finance: The Theory of Capital Market Inflation, Financial Derivatives, and Pension Fund Capitalism. London: Routledge.

Tridico, P., Pariboni, R. (2018). Inequality, financialization and economic decline. Journal of Post Keynesian Economics 41(2): 236-259.

Turner, A. (2016). Between Debt and the Devil. Money, Credit and Fixing Global Finance. Princeton: Princeton University Press.

Urban, D. (2019). Finansyzacja gospodarki w teorii i praktyce. Pomyśleć kapitalizm od nowa. Łódź: Wydawnictwo Uniwersytetu Łódzkiego.

Van der Zwan, N. (2014). Making sense of financialization. Socio-Economic Review 12(1): 99-129. Vercelli, A. (2017). Crisis and Sustainability: The Delusion of Free Markets. Palgrave Macmillan. Woo, H. (2017). Growth Without Inequality. Reinventing Capitalism. New York: Routledge.

Zaremba, A. (2014). Wykorzystanie surowców do dywersyfikacji portfela wobec zjawiska finansjalizacji. Studia Ekonomiczne 2(81): 243-263.

Żelazny, J. (2016). Financialization and commodity market stability. Financial Internet Quarterly E-Finance 12(4): 33-42.

Żyzyński, J. (2010). Neoliberalizm - ślepa uliczka globalizacja, [w:] G. Kołodko (red.). Globalizacja, kryzys i co dalej. Warszawa: Wydawnictwo Poltext: 17-44.

\section{THE FINANCIALIZATION OF THE ECONOMY - A MACROECONOMIC PERSPECTIVE}

\section{Sum mary}

This article attempts a holistic analysis of the phenomenon of the financialization of the economy using a macroeconomic approach. The first part of the article deals with terminological issues. In the second part the author presents the determinants of financialization and the stages of the process from a historical perspective. The third part of this article analyses economic phenomena and business processes linked to financialization: transformation on commodity markets, inflation targeting as a goal of monetary policy, the impact of the financial sector on economic growth and asset inflation on capital markets.

Keywords: financialization; financialization of the economy; commodity market financialization; JEL codes: G00; E00 
